\title{
AS DECISÕES MONOCRÁTICAS NA ESFERA CÍVEL EM CASOS DE INTERVENÇÃO OBRIGATÓRIA DO MINISTÉRIO PÚBLICO - LIMITES E NULIDADES 1
}

\section{MANDATORY PUBLIC PROSECUTOR INTERVENTION IN COURTS OF APPEAL - LIMITS AND NULLITIES}

Ana Maria Moreira Marchesan Procuradora de Justiça no Estado do Rio Grande do Sul. Mestre e Doutora em Direito Ambiental e Biodireito pela Universidade Federal de Santa Catarina. Professora dos Cursos de Pós-Graduação em Direito Ambiental da UFRGS e da FMP. Integrante da Diretoria do Instituto "O Direito por um Planeta Verde". Porto Alegre/RS.

Hermes Zaneti Júnior

Prof. Dr. Dr. Hermes Zaneti Jr. Professor Adjunto de Direito Processual Civil na Graduação e Mestrado da Universidade Federal do Espírito Santo (UFES). Pós-doutorado em Direito Processual pela Università degli Studi di Torino/IT (UNITO). Doutor em Direito, área de concentração Teoria do Direito e Filosofia do Direito, pela Università degli Studi di Roma 3 (UNIROMA3). Doutor e Mestre em Direito, área de concentração Direito Processual, pela Universidade Federal do Rio Grande do Sul (UFRGS). Este artigo é resultado das atividades do grupo de pesquisa "Fundamentos do Processo Civil Contemporâneo", vinculado à Universidade Federal do Espírito Santo (UFES) e cadastrado no Diretório de Grupos de Pesquisa do $\mathrm{CNPq}$ (http://dgp.cnpq.br/dgp/espelhogrupo/0258496297445429(lin

\footnotetext{
${ }^{1}$ Artigo recebido em 10/06/2021 e aprovado em 16/06/2021.
} 
k is external). O Grupo FPCC é fundador da ProcNet - Rede

Internacional de Pesquisa Justiça Civil e Processo Contemporâneo, para obter informações sobre a atividade do grupo acesse o site do LAPROCON - Laboratório de Processo Constitucional UFES (http://laprocon.ufes.br/). Vitória/ES. Email: hermeszanetijr@gmail.com.

RESUMO: O presente artigo aborda a problemática da disseminação de decisões monocráticas proferidas nos tribunais brasileiros fora das hipóteses restritas previstas no Código de Processo Civil. Após uma análise detalhada de como, quando e onde pode haver essa fuga do princípio da colegialidade, enfrenta-se o tema da intervenção do Ministério Público como fiscal da ordem jurídica nos recursos de agravo de instrumento e apelação e a necessária e prévia vista dos autos antes de ser julgado o recurso.

PALAVRAS-CHAVE: Decisões monocráticas. Recursos. Teoria dos precedentes. Intervenção. Ministério Público.

ABSTRACT: This article addresses the issue of the dissemination of monocratic decisions handed down in Brazilian courts outside the restricted assumptions provided for in the Code of Civil Procedure. After a detailed analysis of how, when and where this escape from the principle of collegiality can take place, the theme of the intervention of the Public Prosecutor's Office as an inspector of the legal order in the appeals and interlocutory appeals and the necessary prior view of the case before us is faced.

KEYWORDS: Monocratic decisions. Appeals. Binding precedents. Intervention. Public Prosecutor's.

SUMÁRIO: Introdução. 1. A teoria dos precedentes e a superação da ideia da jurisprudência dominante. A Súmula 568 do STJ. 2. As hipóteses de cabimento de decisões monocráticas no CPC de 2015. 3. A obrigatoriedade de intimação do MP para intervenção no segundo 
grau nas hipóteses previstas em lei. 4. Da nulidade das decisões monocráticas sem prévia oportunidade de intervenção do parquet. 5. Conclusões.

\section{Introdução}

Trata o presente estudo da análise sobre o cabimento das decisões monocráticas proferidas nos tribunais brasileiros no julgamento de recursos de apelação e de agravo de instrumento, com especial foco nos casos em que a legislação brasileira converge para exigir a intervenção do Ministério Público em segundo grau como fiscal da ordem jurídica.

O foco da pesquisa é aclarar quando, como e onde pode o relator do recurso de agravo ou de apelação fugir da regra geral que é a decisão pelo Colegiado para decidir monocraticamente pela inadmissibilidade do recurso ou no mérito. Somente analisaremos as decisões monocráticas com potencial de extinguir o recurso, decisões de urgência não serão analisadas.

Um problema adicional é que grande parte dessas decisões que extinguem o recurso fugindo à regra da colegialidade ocorrem em processos de necessária intervenção do Ministério Público como fiscal da ordem jurídica (arts. 178 e 179 c/c art. 932, VII, CPC). Essa intervenção é obrigatória por força da função constitucional desempenhada pelo Ministério Público de segundo grau, especialmente por serem as apelações e agravos de instrumentos isentas de parecer recursal do Ministério Público de primeiro grau. A intervenção ministerial é obrigatória por força da sua essencialidade e permanência no sistema de justiça como instituição de garantia dos direitos fundamentais, materiais e processuais, nos casos em que é interveniente (art. 127, caput, CF/1988).

O problema é tão grave que a ausência da intimação do Ministério Público não é a única falha procedimental verificável. Igualmente não são raros os casos em que a monocrática irrompe sem que se dê prévia vista para contrarrazões, nas hipóteses de provimento recursal (art. 932, inc. V, do CPC) ${ }^{2}$.

Diagnosticada essa verdadeira patologia ou disfunção processual, que atenta contra o dever geral de cooperação (art. $6^{\circ}, \mathrm{CPC}$ ), o contraditório substancial (válido a partir do

\footnotetext{
${ }^{2}$ Do TJ/RS, podemos citar os seguintes exemplos: Agravo de Instrumento $n^{\circ} 5042528$ 22.2021.8.21.7000/RS, julgado em 17.mar.2021; Agravo de Instrumento $\mathrm{n}^{\circ}$ 5072948-10.2021.8.21.7000/RS, julgado em 26.mai.2021 e Agravo de Instrumento n ${ }^{\circ}$ 5059691-15.2021.8.21.7000/RS, julgado em 01.jun.2021.
} 
novo Código expressamente também para o julgador, com a vedação da decisão surpresa, art. $10 \mathrm{c} / \mathrm{c}$ art. $\left.927, \S 1^{\circ}, \mathrm{CPC}\right)$ e uma série de outros princípios do atual Código de Processo Civil, propõe-se no presente trabalho afirmar a necessidade de superação dessa prática reveladora de uma má compreensão das diferentes competências do relator.

Os julgamentos monocráticos são um importante instrumento de efetividade e celeridade no sistema processual. Contudo, como bem lembrava Barbosa Moreira, em seu clássico estudo sobre os mitos do processo civil, "o quanto mais depressa melhor" não vale a qualquer custo, pois: "Se uma Justiça lenta demais é decerto uma Justiça má, daí não se segue que uma Justiça muito rápida seja necessariamente uma Justiça boa. O que todos devemos querer é que a prestação jurisdicional venha a ser melhor do que é. Se para tornála melhor é preciso acelerá-la, muito bem: não, contudo, a qualquer preço."3

\section{A teoria dos precedentes e a superação da ideia da jurisprudência dominante. A} Súmula 568 do STJ.

O Código de Processo Civil, introduzido através da Lei n 13.105, de 16 de março de 2015, ingressou no Brasil em um novo modelo-guia para a atuação do Poder Judiciário: o dos precedentes normativos formalmente vinculantes. A partir da introdução da teoria dos precedentes no sistema processual civil brasileiro, pela via legal, nomeadamente com a arquitetura jurídica apoiada nos arts. 489, § 1º, V e VI, 926 e 927 do CPC, os tribunais passaram a poder se valer dos precedentes e de sua eficácia vinculativa em todo o arco processual.

A finalidade dessa mudança está em adicionar maior racionalidade ao direito, reduzindo a discricionariedade ${ }^{4}$. O conjunto de decisões de um tribunal ainda continua se chamando jurisprudência, mas essa passa a ser geralmente persuasiva e exemplificativa.

\footnotetext{
${ }^{3}$ MOREIRA, José Carlos Barbosa. O Futuro da Justiça: alguns mitos. Revista síntese de direito civil e processual civil, Porto Alegre, n. 6 -, p. 39., Jul-./Ago. 2000.

4 A respeito das consequências do modelo inaugurado pelo CPC de 2015 relacionado aos precedentes vinculantes são inegáveis as vantagens para a própria magistratura derivadas da redução da discricionariedade. "A liberdade absoluta degenera-se em arbítrio para o cidadão e, em risco, para a magistratura. Assim, a redução da discricionariedade dos juízes e tribunais, aumenta a independência e a autonomia destes em relação aos demais poderes, pois a diminuição da subjetividade decisória evita a exposição dos julgadores a pressões políticas e sociais de ocasião, já que estarão vinculados unicamente à lei e aos precedentes" (ZANETI JÚNIOR, Hermes. Comentários ao art. 926. In: CABRAL, Antonio do Passo; CRAMER, Ronaldo. Comentários ao Novo Código de Processo Civil. 2. ed. São Paulo: Saraiva, 2016, p. 1314-1315).
} 
Entretanto, algumas dessas decisões por força da introdução do rol formal do art. 927 (ampliado todas as vezes que órgãos fracionários fizerem às vezes de pleno nos tribunais, como é o caso das Seções do STJ, no julgamento dos embargos de divergência) e do conteúdo material previsto nos arts. $489, \S 1^{\circ}$, V e VI e 926 , é que poderá ser denominado de precedentes, no sentido vinculante. São vinculantes porque a legislação processual previu que serão "observados" por todos os juízes e tribunais e porque têm o conteúdo normativo de decisões de casos-precedentes que se aplicam aos casos-atuais. Para as mesmas circunstâncias fáticas deverá o julgador aplicar a mesma solução jurídica (treat like cases alike).

Portanto, mercê da introdução de um rol não exaustivo, mas bastante amplo, de decisões e técnicas para externalização e veiculação das decisões (súmulas e teses jurídicas), o legislador processual civil tratou de disciplinar sobre a força normativa desses instrumentos criados a partir da identificação da ratio decidendi do caso-precedente, ou seja, dos fundamentos determinantes, e da relação desses fundamentos com os casos submetidos a julgamento (art. $\left.489, \S 1^{\circ}, \mathrm{V}\right)^{5}$.

Dimana desse modelo-guia que os casos de aplicação a partir das súmulas devem decorrer da identificação das circunstâncias fáticas e dos precedentes que lhes deram origem (art. 926, $\S 2^{\circ}$ ), garantindo que a aplicação do caso-precedente decorra sempre da análise da unidade fático-jurídica da decisão anterior em relação ao caso-atual, revelando, assim, o conteúdo do que deve ser considerado normativo.

O mesmo modelo prevê, ainda nos aspectos materiais, a técnica a ser empregada pelo juiz ou tribunal que opte por deixar de seguir enunciado de súmula, jurisprudência ou precedente invocado pela parte. Nesses casos, deve o julgador demonstrar a existência de distinção no caso em julgamento ou a superação do entendimento assumido pelas súmulas, jurisprudência ou precedente invocado, sob pena da decisão interlocutória, sentença ou acórdão ser considerado não fundamentado (art. 489, § $1^{\circ}$, VI).

Cabe, no ponto, perscrutar o sentido de precedente. Não é o mesmo que decisão judicial colegiada, muito menos monocrática, emanada de tribunal, mesmo dos superiores.

\footnotetext{
${ }^{5}$ ZANETI JÚNIOR, Hermes. Poderes do Relator e Precedentes no CPC/2015: perfil analítico do art. 932, IV e V. In: NUNES, Dierle José Coelho. A nova aplicação da jurisprudência e precedentes no CPC/2015: estudos em homenagem à professora Teresa Arruda Alvim. São Paulo: Revista dos Tribunais, 2017, p. 525544.
} 
Precedente é definido, numa concepção restritiva, como aquele caso que venha a acrescentar uma glosa, um acréscimo aos textos legais para decidirem determinada questão jurídica ${ }^{6}$. Uma interpretação operativa, que inclui um conto, aumenta um ponto, na narrativa do romance em cadeia que constitui a interpretação e aplicação do direito para os casos concretos.

O julgamento, ainda que colegiado e oriundo de Corte Suprema (no Brasil, STJ e STF), que apenas aplique a lei sem qualquer acréscimo interpretativo, sem esclarecer uma dúvida de incidência ou uma colisão de princípios, não é considerado precedente ${ }^{7}$, pela simples razão de que a vinculação decorre da lei e não à decisão. Os juízes estão vinculados à lei, e quando precisam interpretar a lei (com maior intensidade) essa interpretação se universaliza e deve ser a mesma para todos os casos futuros, logo, uma interpretação que forma um precedente (a depender de quem julgou o caso), vinculando vertical e horizontalmente os juízes e tribunais.

É imperativo que os tribunais respeitem seus próprios precedentes (vinculação horizontal), premissa sem a qual sequer se pode cogitar do modelo de precedentes normativos vinculantes. A vinculação horizontal está clara quando o CPC determina que os tribunais devem manter os seus precedentes estáveis, íntegros e coerentes.

\footnotetext{
${ }^{6}$ MARCHESAN, Ana Maria Moreira. O fato consumado em matéria ambiental. Salvador: JusPodivm, 2019 , p. 205.

${ }^{7}$ ZANETI JÚNIOR, Hermes. O valor vinculante dos precedentes: teoria dos precedentes normativos formalmente vinculantes. 3. ed. Salvador: Editora JusPodivm, 2017, p. 333-334. Posição semelhante é sustentada por MARINONI, Luiz Guilherme. Precedentes obrigatórios. São Paulo: Revista dos Tribunais, 2010, p. 216. Convém não confundir o que se está defendendo neste texto com outra questão, trazida por Didier Júnior, Braga e Oliveira, que utilizam um conceito abrangente de precedentes, incluindo os precedentes persuasivos; precedentes são compreendidos como aquelas decisões que vêm antes, portanto, qualquer decisão anterior é precedente. Para esse grupo de processualistas civis, precedente é qualquer decisão que constitua uma norma para o caso concreto e um precedente para os futuros casos ainda que meramente persuasiva. Não há nenhum erro aqui, essa aliás é a teoria dos precedentes persuasivos, utilizados pelas boas-razões. O que não se está tratando neste texto, pois a novidade no Brasil são justamente os precedentes normativos formalmente vinculantes, esses que autorizam, entre outras coisas, as decisões monocráticas do relator pelo Código atual. Para os precedentes persuasivos já temos escola e conhecimento, são a antigas frases feitas, a "jurisprudência dominante", compreendida como conjunto de casos em um ou outro sentido, da qual se valiam os recorrentes conforme o sentido estivesse a seu favor, e se valiam os juízes (e ainda se valem) para decidir conforme bementendessem ser o caso, ainda que contra o que entende o STJ ou o STF na matéria. A jurisprudência persuasiva é igual aos precedentes persuasivos, depende do gosto e da conveniência. Tem uma função, mas não serve para ser aplicada em julgamentos monocráticos. Para o conceito amplo de precedentes como as decisões que são anteriores ao caso que se está decidindo, conferir DIDIER JÚNIOR, Fredie; BRAGA, Paula Sarno; OLIVEIRA, Rafael. Curso de direito processual civil: teoria da prova, direito probatório, teoria do precedente, decisão judicial, coisa julgada e antecipação dos efeitos da tutela. 9. ed. Salvador: JusPodivm, 2014 , v. 2, p. 281-282.
} 
Afastada a relação de vinculatividade para os próprios órgãos que estabelecem as decisões com caráter vinculante para os órgãos inferiores, o modelo de precedentes se tornaria inseguro e não racional, um "alvo móvel", fomentando caos e incerteza, contrariando suas funções (art. 926, caput). Obrigar os tribunais e juízes inferiores, vinculados verticalmente, a seguir decisões flutuantes equivale a negar a própria função dos tribunais superiores como Cortes Supremas ${ }^{8}$.

A função dos tribunais como Cortes Supremas (cortes de garantia da unidade do direito, e não de mera correção de decisões, cortes de precedentes, e não de jurisprudência persuasiva) é inerente e necessária ao momento atual do direito, no qual a centralidade da interpretação e a dissociação entre texto e norma afastam totalmente os valores da "textualidade" decorrentes do formalismo interpretativo?.

Hodiernamente, a questão referente aos precedentes no Brasil distancia-se das antigas polêmicas sobre a criação do direito pelos juízes e da atividade potencialmente legislativa desses juízes na tomada de decisão, visto que decorre da atividade de interpretação operativa, de glosa à legislação, natural ao trabalho dos juízes e tribunais. Afasta-se também da visão dicotômica das tradições jurídicas civil law e common law como antagônicas, pois se trata de um problema típico da teoria do direito contemporâneo, ao qual todos os ordenamentos jurídicos, independentemente da tradição à qual estejam filiados, precisam responder, se almejam racionalidade.

A Súmula 568 do Superior Tribunal de Justiça vem sendo empregada para supostamente justificar decisões monocráticas que não se acham autorizadas pelo atual diploma processual. O verbete diz o seguinte: "O relator, monocraticamente e no Superior Tribunal de Justiça, poderá dar ou negar provimento ao recurso quando houver entendimento dominante acerca do tema. Referência: CF, art. 105, III, a e c. Precedentes: REsp 503.701RS (2 $2^{\mathrm{a}} \mathrm{T}, 22.06 .2004$ - DJ 18.10.2004) REsp 1.501.205-RS (2 ${ }^{\mathrm{a}} \mathrm{T}, 21.05 .2015$ - DJe 30.05.2015)".

\footnotetext{
${ }^{8}$ ZANETI JÚNIOR, Hermes. Poderes do Relator e Precedentes no CPC/2015: perfil analítico do art. 932, IV e V. In: NUNES, Dierle José Coelho. A nova aplicação da jurisprudência e precedentes no CPC/2015: estudos em homenagem à professora Teresa Arruda Alvim. São Paulo: Revista dos Tribunais, 2017, p. 525). ${ }^{9}$ ZANETI JÚNIOR, Hermes. Poderes do Relator e Precedentes no CPC/2015: perfil analítico do art. 932, IV e V. In: NUNES, Dierle José Coelho. A nova aplicação da jurisprudência e precedentes no CPC/2015: estudos em homenagem à professora Teresa Arruda Alvim. São Paulo: Revista dos Tribunais, 2017, p. 525).
} 
Já na indicação dos precedentes é possível aferir que essa súmula foi construída em período anterior ao novo CPC que aderiu ao modelo-guia dos precedentes vinculantes. $\mathrm{O}$ contexto em que o enunciado da súmula foi exarado parece indicar um retorno ao modelo anterior, à prática do STJ em relação ao antigo art. 557, CPC/1973. A interpretação do artigo 557 do CPC/1973 era ruim, contraditória e gerava caos decisório, enfraquecendo a confiança legítima dos jurisdicionados no sistema de justiça, abrindo espaço para confundir o entendimento do relator como sendo o "dominante".

O enunciado da Súmula 568 deve ser interpretado em conformidade com a Constituição e com o modelo de precedentes, e por "entendimento dominante" deve ser compreendido o entendimento fixado em súmula ou nos demais casos previstos no art. 927 e incisos, $\mathrm{CPC} / 2015^{10}$.

Caso contrário, incorrer-se-á naquilo que Vasconcelos e Carnaúba ${ }^{11}$ denominaram de "farra das decisões monocráticas" em detrimento ao contraditório e devido processo legal (muitas delas são proferidas sem prévia vista à parte recorrida para contrarrazões e sem a abertura de vista do Ministério Público no segundo grau) e sem uma fundamentação que demonstre um real cotejo entre o caso em julgamento e a súmula ou precedente invocado como razão de decidir. Esse proceder de optar pela decisão unipessoal fora dos casos previstos em lei, beira o arbítrio judicial e afronta uma das bases do atual processo civil que é a ideia de cooperação entre todos os atores do processo $^{12}$.

O próprio STJ tem sido iterativo no sentido de que, apesar de não ter de rever "todas" as alegações das partes, o juiz deve enfrentar aquelas capazes de "infirmar a sua decisão"13 e, por consequência, não pode aplicar um precedente sem ouvir os argumentos do Ministério

\footnotetext{
${ }^{10}$ ZANETI JÚNIOR, Hermes. Poderes do Relator e Precedentes no CPC/2015: perfil analítico do art. 932, IV e V. In: NUNES, Dierle José Coelho. A nova aplicação da jurisprudência e precedentes no CPC/2015: estudos em homenagem à professora Teresa Arruda Alvim. São Paulo: Revista dos Tribunais, 2017, p. 542.

${ }^{11}$ VASCONCELOS, Ronaldo; CARNAÚBA, César Augusto. Agravo interno e a decisão monocrática fundada em precedente vinculante: entre a farra, o arbítrio e a prudência. Revista do Processo, vol. 293, 2019, p. 220.

${ }^{12}$ Mitidiero faz um alerta merecedor de destaque: "É fundamental, na organização do formalismo de um modelo de processo civil inspirado na colaboração, que se levem em consideração os pontos de vista externados pelas partes ao longo do procedimento no quando da decisão da causa. Trata-se de exigência calcada na necessidade de participação de todos que tomam parte no processo para o alcance da justa solução do caso concreto, tendo o diálogo papel de evidente destaque nessa estruturação. Fora dessas coordenadas não há falar em cooperação no processo" (MITIDIERO, Daniel. Colaboração no processo civil: pressupostos sociais, lógicos e éticos. São Paulo: Revista dos Tribunais, 2009. p. 137-138).

${ }^{13}$ EDcl no MS 21.315/DF, Rel. Ministra Diva Malerbi (Desembargadora convocada TRF $3^{a}$ Região), Primeira Seção, julgado em 8/6/2016, DJe 15/6/2016.
} 
Público sobre a aplicação ou não deste precedente, quando este deve intervir, por força da Constituição e do CPC (arts. 178, 179, 932, VII), sob pena de nulidade (art. 279, CPC).

A partir dessas digressões, importante desde já lançar a seguinte premissa: uma visão coerente com o modelo de precedentes afasta a possibilidade de decisões arbitrárias pelo relator que estejam vinculadas tão somente às convicções pessoais quanto ao que pensa ser a melhor jurisprudência do tribunal. Dito de outro modo: preconiza-se nesse trabalho a não adoção de uma noção subjetiva de jurisprudência dominante, objetivando demonstrar que, para a adequação e constitucionalidade do modelo-guia, deverá ser conferida à expressão jurisprudência dominante uma interpretação conforme o modelo normativo formal e material dos precedentes vinculantes no atual CPC.

\section{As hipóteses de cabimento de decisões monocráticas no CPC de 2015.}

A regra geral do julgamento dos recursos pelos tribunais é a do princípio da colegialidade. Tal conclusão dimana diretamente da própria composição dos órgãos fracionários das cortes brasileiras, todos eles integrados por no mínimo três magistrados.

Da estruturação de nossos tribunais em colégios de julgadores decorre a premissa de que a preferência recai sobre decisões conjuntas, ou seja, vereditos recursais em tese seriam mais qualificados, pela presença de discussões em grupo, em relação aos singularmente tomados ${ }^{14}$. Pressupõe-se que a decisão unipessoal ou monocrática "é exceção dentro de um sistema de cortes deliberativas que preza por manifestações colegiadas" ${ }^{15}$.

A materialização desses julgados revela-se através dos acórdãos (art. 163 do CPC/73 e art. 204 do CPC/15), os quais são definidos pelo Conselho Nacional de Justiça como sendo a “decisão tomada não apenas por uma pessoa ou instituição, mas sim a partir do

\footnotetext{
14 “'A ciência ensina-nos, hoje, que a assembleia não nos veio da reflexão; foi a reflexão que veio da assembleia. Essa prioridade do exame múltiplo ao mesmo tempo, em relação ao exame de um só, se transforma em superioridade sempre que desejamos maior certeza. A colegialidade para a decisão dos recursos obedece a esse pendor íntimo do homem quando se deseja guiar pela "razão" (PONTES DE MIRANDA, Francisco Cavalcanti. Comentários ao Código de Processo Civil. Rio de Janeiro: Forense, 1975. t. VII. p. 11).

${ }^{15}$ VASCONCELOS, Ronaldo; CARNAÚBA, César Augusto. Agravo interno e a decisão monocrática fundada em precedente vinculante: entre a farra, o arbítrio e a prudência. Revista do Processo, vol. 293, 2019, p. 224. "Exatamente por ser um paliativo - e não apresentar as qualidades que justificam a escolha por julgamentos colegiados na segunda instância - é que a decisão monocrática deve ser combatida numa pluralidade de hipóteses: para garantir que, sendo necessário, a questão submetida ao tribunal seja realmente apreciada por um órgão colegiado" (Idem).
} 
entendimento entre todos os membros do colegiado (conjunto de julgadores), que após análises e deliberações chegam a uma sentença em conjunto" ${ }^{16}$.

Diante dos esforços empreendidos pelos reformadores do Código de Processo Civil no sentido de agilizar o curso dos processos, assegurando-lhes um prazo de razoável duração, estabeleceu-se todo um sistema de precedentes e foram pinçadas exaustivamente algumas hipóteses em que pode o relator julgar monocraticamente, sem afronta ao princípio da colegialidade.

O rol de decisões monocráticas admitidas pelo CPC/2015 consta do art. 932.

Destacaremos, a seguir, tão somente aquelas que serão objeto do presente estudo:

Art. 932. Incumbe ao relator:

(...)

III - não conhecer de recurso inadmissível, prejudicado ou que não tenha impugnado especificamente os fundamentos da decisão recorrida;

IV - negar provimento a recurso que for contrário a:

a) súmula do Supremo Tribunal Federal, do Superior Tribunal de Justiça ou do próprio tribunal;

b) acórdão proferido pelo Supremo Tribunal Federal ou pelo Superior Tribunal de Justiça em julgamento de recursos repetitivos;

c) entendimento firmado em incidente de resolução de demandas repetitivas ou de assunção de competência;

$\mathrm{V}$ - depois de facultada a apresentação de contrarrazões, dar provimento ao recurso se a decisão recorrida for contrária a:

a) súmula do Supremo Tribunal Federal, do Superior Tribunal de Justiça ou do próprio tribunal;

b) acórdão proferido pelo Supremo Tribunal Federal ou pelo Superior Tribunal de Justiça em julgamento de recursos repetitivos;

c) entendimento firmado em incidente de resolução de demandas repetitivas ou de assunção de competência;

VI - decidir o incidente de desconsideração da personalidade jurídica, quando este for instaurado originariamente perante o tribunal; (...).

Didier Jr. e Carneiro da Cunha ${ }^{17}$, ao examinarem os incs. IV e V do art. 932 do CPC, observam que, diferentemente do que fizera o CPC-1973 (art. 557),

o CPC-2015 conferiu esse poder ao relator apenas em hipóteses específicas, todas elas relacionadas ao sistema de precedentes obrigatórios (art. 927, CPC). (...) Não pode o relator julgar sozinho o recurso quando bem entender, ou em hipóteses atípicas como de "manifesta procedência" ou "evidente improcedência". O julgamento unipessoal de mérito, pelo relator, deve ser considerado, portanto, como

${ }^{16}$ CNJ Serviço: saiba quando a decisão final é dada por sentença ou em acórdão. Disponível em: https://www.cnj.jus.br/cnj-servico-saiba-quando-a-decisao-final-e-dada-por-sentenca-ou-em-acordao/ Acesso em 19.abr.2021.

${ }^{17}$ DIDIER JR., Fredie. Curso de direito processual civil: o processo civil nos tribunais, recursos, ações de competência originária de tribunal e querela nullitatis, incidentes de competência originária de tribunal 13.ed. reform. Salvador: Ed. Juspodvm, 2016. p. 55. 
hipótese excepcional, que foge à regra da colegialidade das decisões em tribunal.

O CPC/1973, em seu art. 557, caput, nada dispunha quanto a negar seguimento/provimento a recurso que fosse contrário a tese firmada em acórdão proferido no âmbito do STF. Assim, o art. 932, inciso IV, alínea "b" do CPC/2015 é inovador também neste aspecto, uma vez que, doravante, o acórdão firmado pela Suprema Corte em recurso repetitivo ou repercussão geral é motivo autorizador para negativa de provimento de recurso pela instância inferior.

Aqui, a grande novidade é a eliminação da possibilidade antes prevista no CPC/1973 de o relator negar seguimento/provimento ao recurso que fosse contrário à "jurisprudência dominante" do respectivo tribunal do Supremo Tribunal Federal ou de Tribunal Superior. Portanto, não está congruente com o CPC vigente a ementa da Súmula 568 do STJ - grifamos.

Assentada a ideia de taxatividade dos casos elencados de possibilidade de julgamento monocrático de recurso, passaremos agora à análise de cada um deles.

\subsection{Não conhecimento de recurso inadmissível, prejudicado ou que não tenha impugnado especificamente os fundamentos da decisão recorrida:}

A primeira hipótese a ser escrutinada diz respeito ao não conhecimento de recurso manifestamente inadmissível (agravo de instrumento interposto contra interlocutória não prevista dentre as hipóteses do art. 1015 do $\mathrm{CPC}^{18}$, como por exemplo, aquela que indefere a expedição de ofício para verificação de inadimplência de financiamento ${ }^{19}$ ).

Decisões interlocutórias são definidas pelo próprio diploma adjetivo como "todo pronunciamento judicial de natureza decisória que não se enquadre no $\S 1^{\circ}$ " (art. 203, $\S 2^{\circ}$ ). Da leitura da definição extrai-se que o legislador optou por defini-las pelo que elas não são. Dito de outra forma, todo o pronunciamento judicial pelo qual o juiz decide algo que não ponha fim à fase cognitiva do procedimento comum nem extinga a execução, pode ser considerado decisão interlocutória. Todavia, os casos são restritos "a priori” às hipóteses expressamente arroladas no já citado art. 1015, as quais desafiam a interposição do agravo de instrumento.

Diz-se "a priori" porque a jurisprudência vem alargando as hipóteses de cabimento. A Corte Especial do STJ, em dezembro de 2018, na apreciação do REsp 1.704.520,

\footnotetext{
${ }^{18}$ Em que pese aludido dispositivo trazer um rol supostamente exaustivo dos casos de cabimento de agravo de instrumento, a jurisprudência vem alargando essas hipóteses.

${ }^{19}$ RIO GRANDE DO SUL. Tribunal de Justiça. Agravo de Instrumento № 5058785-25.2021.8.21.7000. Rel. Des. Carlos Eduardo Zietlow Duro. J. em 19.abr.2021.
} 
construiu a noção de taxatividade mitigada pelo requisito da urgência do rol previsto no art. 1.015 CPC, admitindo outros casos de interposição do agravo de instrumento em hipóteses diversas das expressamente contidas no texto legal, como, por exemplo, em verificada a urgência derivada da inutilidade quando do julgamento da questão no recurso de apelação, conforme sentenciou a Ministra Nancy Andrighi, o que está na base da tese dos recursos repetitivos no Tema $\mathrm{n}^{\mathrm{o}} 988^{20}$.

Portanto, o clássico exemplo de não conhecimento de recurso manifestamente inadmissível é o que se materializa na interposição do agravo de instrumento fora daquelas hipóteses contidas no referido dispositivo e no conjunto de precedentes judiciais que mitigaram, em face da urgência, o rol supostamente exaustivo do art. 1015 do CPC.

Recurso prejudicado ${ }^{21}$, por sua vez, é aquele para cujo julgamento a parte recorrente não mais ostenta interesse jurídico em sua apreciação. Quando o juiz de primeiro grau, por exemplo, ao receber a petição de interposição do agravo de instrumento, muda a sua decisão, cabe ao relator julgar prejudicado o recurso (art. 1018, § $1^{\circ}$, do $\mathrm{CPC}$ ). Igualmente prejudicado restará o recurso daquela parte que aceitou de forma expressa ou tácita uma decisão (ex. celebrou um acordo no primeiro grau de Jurisdição assumindo as obrigações impostas na decisão recorrida).

A terceira hipótese contida no inc. III do art. 932 do CPC diz respeito ao chamado princípio da dialeticidade, do qual dimana a necessária pertinência temática entre as razões de decidir e os fundamentos fornecidos pelo recorrente para justificar o pedido de reforma ou nulidade do julgado ${ }^{22}$. Não há de ser conhecido o recurso que não impugna especificamente os fundamentos da decisão agravada, consoante a Súmula 182 do STJ: "É inviável o agravo do artigo 545 do CPC[73] que deixa de atacar especificamente os fundamentos da decisão agravada".

${ }^{20}$ BRASIL. Superior Tribunal de Justiça. REsp 1704520. Relatora: Min. Nancy Andrighi. Julgado em $19 / 12 / 2018$. https://processo.stj.jus.br/processo/revista/documento/mediado/?componente $=$ ATC\&sequencial $=85913737 \&$ num_registro $=201702719246 \&$ data $=20181219 \&$ tipo $=51 \&$ formato $=P D F$

21 "Recurso prejudicado é aquele que perdeu seu objeto. Ocorrendo a perda do objeto, há falta superveniente de interesse recursal, impondo-se o não conhecimento do recurso por ausência de requisito de admissibilidade. Assim, ao relator cabe julgar inadmissível o recurso por falta de interesse, ou seja, julgá-lo prejudicado" (NERY JÚNIOR, Nelson; NERY, Rosa Maria Andrade. Comentários ao Código de Processo Civil. 1.ed. São Paulo: Revista dos Tribunais, 2015, p. 1851).

${ }^{22}$ BRASIL. Superior Tribunal de Justiça. REsp 1769338. Relator Min. HERMAN BENJAMIN. Julgado em 08.nov.2018. Disponível em: https://corpus927.enfam.jus.br/inteiro-teor/9en6ndb5j81w Acesso em 21.abr.2021. 


\subsection{Negativa de provimento a recurso que for contrário à súmula do Supremo Tribunal Federal, do Superior Tribunal de Justiça ou do próprio tribunal:}

O inc. IV do art. 932 do CPC trata do dever do relator de negar provimento a recurso contrário à Súmula do STF, do STJ ou do próprio Tribunal que ele integra. Há um nítido compromisso do legislador reformista de redução do campo de discricionariedade nas decisões, pacificando a jurisprudência e conferindo maior consistência e coerência ao conjunto de decisões de cada tribunal.

Em relação ao CPC anterior, importante destacar ter sido suprimida a hipótese de “jurisprudência dominante” que figurava no art. 557 do CPC/1973, com a seguinte redação:

Art. 557. O relator negará seguimento a recurso manifestamente inadmissível, improcedente, prejudicado ou em confronto com súmula ou com jurisprudência dominante do respectivo tribunal, do Supremo Tribunal Federal, ou de Tribunal Superior. - grifos nossos

Em que pese essa alteração, na prática muitos julgadores persistem proferindo decisões monocráticas simplesmente pautados pela ideia de seguimento à "jurisprudência dominante" do próprio relator, da câmara ou turma do tribunal, o que não havia antes e menos ainda há no vigente CPC. Neves considera inaceitável essa interpretação alargada das hipóteses do art. 932, inc. IV, porquanto o espírito do novel diploma é de conferir maior segurança jurídica às decisões unipessoais ${ }^{23}$.

A expressão "jurisprudência dominante" foi sabiamente retirada das possibilidades de decisão monocrática, justamente por se tratar de um conceito jurídico indeterminado. A novel redação contida no referido inc. IV confere maior segurança e exige do julgador a menção expressa em seu ato decisório monocrático à súmula e respectiva Corte que a prolatou, mediante um cotejo analítico entre o caso sub judice e referido enunciado.

Marinoni explicita bem a técnica a ser empregada:

É intuitivo que, para aplicar a ratio decidendi a um caso, é necessário comparar o caso de que provém a ratio decidendi com o caso sob julgamento, analisando-se as suas circunstâncias fáticas. Isso significa uma diferenciação ou distinção de casos, que assume a forma de técnica jurídica voltada a permitir a aplicação dos precedentes. Nesse sentido fala-se, no common law, em distinguishing. $\mathrm{O}$ distinguishing expressa a distinção entre casos para o efeito de se subordinar, ou não, o caso sob julgamento a

${ }^{23}$ NEVES, Daniel Amorim Assumpção. Manual de direito processual civil. 8. ed. Salvador: JusPodivm, 2016, p. 2377. 
um precedente. A necessidade de distinguishing exige, como antecedente lógico, a identificação da ratio decidendi do precedente. Como a ratio espelha o precedente que deriva do caso, trata-se de opor o caso sob julgamento à ratio do precedente decorrente do primeiro caso ${ }^{24}$.

Observe-se que a expressão jurisprudência dominante segue presente no CPC atual, porém nos arts. $926, \S 1^{\circ}, 927, \S 3^{\circ}$ e $1035, \S 3$. O primeiro dispositivo orienta sobre como devem se formar as súmulas nos tribunais. $\mathrm{O}$ segundo rege a sistemática para alteração de jurisprudência dominante, preferencialmente aquela convertida em súmula, do Supremo Tribunal Federal e dos tribunais superiores ou daquela oriunda de julgamento de casos repetitivos. O terceiro trata dos casos de repercussão geral para fins de acesso recursal aos tribunais superiores.

Nitidamente, o CPC fez um corte dogmático para impedir que o conceito de jurisprudência dominante fosse de livre escolha dos seus operadores ${ }^{25}$.

Importante ressalvar, neste ponto, que os regimentos internos dos tribunais não estão livres para dispor de forma ampliada em relação aos casos de decisões monocráticas.

No Tribunal de Justiça do Rio Grande do Sul, por exemplo, muitos casos são decididos de forma monocrática com base no art. 206, inc. XXXVI, do Regimento Interno do TJ/RS assim vazado:

Art. 206. Compete ao relator:

(...)

XXXVI - negar ou dar provimento ao recurso quando houver jurisprudência dominante acerca do tema no Supremo Tribunal Federal e Superior Tribunal de Justiça com relação, respectivamente, às matérias constitucional e infraconstitucional e deste Tribunal; (grifamos)

Ocorre que, para a correta subsunção da decisão a esse dispositivo regimental, o relator deve indicar em seu ato decisório qual a jurisprudência dominante dos tribunais superiores ou do próprio Tribunal na qual se baseia e, mais do que isso, demonstrar o conjunto de precedentes invocados e realizar um cotejo analítico com o caso em mesa de julgamento ${ }^{26}$.

\footnotetext{
${ }^{24}$ MARINONI, Luiz Guilherme. Precedentes obrigatórios. São Paulo: Revista dos Tribunais, 2010. p. 326.

${ }^{25}$ ZANETI JÚNIOR, Hermes. Poderes do Relator e Precedentes no CPC/2015: perfil analítico do art. 932, IV e V. In: NUNES, Dierle José Coelho. A nova aplicação da jurisprudência e precedentes no CPC/2015: estudos em homenagem à professora Teresa Arruda Alvim. São Paulo: Revista dos Tribunais, 2017, p. 526. ${ }^{26}$ Vasconcelos e Carnaúba advertem para as possíveis consequências nocivas geradas pela não realização dessas amarrações. 'O relator, no meio da balbúrdia feita pelo sistema de 'precedentes' - que reúne precedentes, súmulas, jurisprudência vinculante e decisões moleculares de conflitos - pode acabar fazendo o que bem entende, utilizando este ou aquele julgado para fundamentar ou não esta ou aquela decisão. E quem sai perdendo é o jurisdicionado" (VASCONCELOS, Ronaldo; CARNAÚBA, César Augusto. Agravo interno
} 
A expressão jurisprudência dominante não pode ser interpretada da forma elástica como vinha sendo feita sob a égide do anterior diploma adjetivo. Justamente pela escassez de densidade que ela carreia, o novo Código tratou do assunto com uma clareza muito maior, não mais permitindo a obtusa interpretação de entender por jurisprudência dominante a da própria turma ou câmara e, em casos extremos, a jurisprudência dominante do próprio relator ${ }^{27}$.

$\mathrm{O}$ atual CPC avança na consolidação formal do chamado stare decisis et quieta non movere, "isto é, mantenha-se o que foi decidido e não se disturbe a paz"28.

Esse preceito implica o dever de considerar, dever de interpretar e dever de aplicar o precedente para solucionar o caso concreto $^{29}$. Ele se desdobra em duas dimensões: a horizontal e a vertical. A primeira constrange o próprio tribunal a manter os seus precedentes estáveis, íntegros e coerentes. Na dicção do art. 926, deduz-se que as Cortes Superiores têm de procurar estabilizar seus próprios precedentes, assim como os tribunais inferiores devem se ater à jurisprudência vinculante (arts. 926 e 927, incs. III e V, CPC).

A dimensão vertical apregoa que todos os juízes e tribunais devem seguir os precedentes e a jurisprudência vinculante das cortes hierarquicamente mais elevadas na estrutura judiciária (arts. 926 e 927 do CPC).

Portanto, o conceito de jurisprudência dominante ${ }^{30}$ no novo CPC é muito mais complexo e sofisticado do que aquele que vem sendo utilizado por alguns tribunais para justificar decisões monocráticas. Compõe-se por precedentes normativos formalmente vinculantes, em especial, mas não unicamente, os sumulados.

É o efeito de precedente vinculante que permite o julgamento pelo relator, e é esse efeito que adere aos enunciados das súmulas, desde que observem a ratio decidendi

\footnotetext{
e a decisão monocrática fundada em precedente vinculante: entre a farra, o arbítrio e a prudência. Revista do Processo, vol. 293, 2019, p. 229).

${ }^{27}$ ZANETI JÚNIOR, Hermes. Poderes do Relator e Precedentes no CPC/2015: perfil analítico do art. 932, IV e V. In: NUNES, Dierle José Coelho. A nova aplicação da jurisprudência e precedentes no CPC/2015: estudos em homenagem à professora Teresa Arruda Alvim. São Paulo: Revista dos Tribunais, 2017, p. 526. ${ }^{28}$ MARINONI, Luiz Guilherme; MITIDIERO, Daniel e ARENHART, Sérgio Cruz. Comentários ao Código de Processo Civil: arts. 926 ao 975. 2. ed. São Paulo: Thomson Reuters Brasil, 2018, p. 24-25.

${ }^{29}$ MARINONI, Luiz Guilherme; MITIDIERO, Daniel e ARENHART, Sérgio Cruz. Comentários ao Código de Processo Civil: arts. 926 ao 975. 2. ed. São Paulo: Thomson Reuters Brasil, 2018, p. 25.

30 "Não é jurisprudência dominante a formada por um único órgão deliberativo; havendo competência para mais de um órgão do tribunal na matéria respectiva, deverão estar assentes todos os órgãos.(...) Também não se coaduna com o conceito de jurisprudência dominante a jurisprudência mal determinada pela ausência de coerência e identificação interna entre os precedentes" (ZANETI JÚNIOR, Hermes. A constitucionalização do processo. 2. ed. São Paulo: Atlas, 2014, p. 240).
} 
(fundamentos determinantes, circunstâncias fáticas e solução jurídica, conforme art. 489, § $\left.1^{\mathrm{o}}, \mathrm{V}\right)$ dos casos-precedentes que lhes deram origem e sejam relacionados com o caso-atual.

A identificação dos fundamentos determinantes do precedente (circunstâncias fáticas e solução jurídica) somada ao cotejo analítico demonstrativo de que esses se ajustam ao caso sob julgamento autorizam a decisão monocrática pelo relator. Não basta a simples referência vazia aos dispositivos do CPC e, eventualmente, do Regimento Interno do respectivo tribunal sem a comparação e justificação quanto ao paralelismo entre os casos.

Portanto, é correta a afirmação de que:

Os precedentes são vertidos em textos que dizem respeito a determinados casos. Isso quer dizer que, como todo e qualquer texto, não dispensa interpretação (nada obstante tenham por função reduzir a equivocidade inerente ao discurso das fontes legislativas) a respeito do significado da linguagem empregada e a propósito do respectivo âmbito de aplicação. Daí que trabalhar com precedentes significa individualizar razões e conectá-las às hipóteses fático-jurídicas que nelas recaem. Por essa razão, trabalhar com precedentes não significa de modo nenhum simplesmente alinhar julgados - condensados ou não em súmulas - sem individualizar as suas origens, os seus significados e a pertinência que guardam com o caso concreto $^{31}$

A incorporação pelo CPC do sistema stare decisis fortalece a segurança jurídica e, via reflexa, os próprios tribunais. Contrariamente ao que possa parecer, não há e não deve haver uma fuga da colegialidade e uma proliferação de decisões monocráticas que não observam a complexidade da legislação processual civil.

\subsection{Negativa de provimento a recurso contrário a acórdão proferido pelo Supremo} Tribunal Federal ou pelo Superior Tribunal de Justiça em julgamento de recursos repetitivos e entendimento firmado em incidente de resolução de demandas repetitivas ou de assunção de competência:

$\mathrm{Na}$ linha da vinculação aos precedentes aparece o dever, prima facie, do relator decidir em conformidade com acórdão proferido pelos tribunais superiores (STF e STJ) em julgamento de recursos repetitivos e entendimento firmado em incidente de resolução de demandas repetitivas ou de assunção de competência.

\footnotetext{
${ }^{31}$ MARINONI, Luiz Guilherme; ARENHART, Sérgio Cruz; MITIDIERO, Daniel. Novo Código de Processo Civil Comentado. São Paulo: Ed. RT, 2015. p. 493-494.
} 
Trataremos em bloco as hipóteses das alíneas "b" e "c" do inc. IV do art. 932 do CPC porque houve, de parte do legislador, certa confusão de conceitos.

No art. 928 está dito:

Art. 928. Para os fins deste Código, considera-se julgamento de casos repetitivos a decisão proferida em:

I - incidente de resolução de demandas repetitivas;

II - recursos especial e extraordinário repetitivos.

Parágrafo único. O julgamento de casos repetitivos tem por objeto questão de direito material ou processual.

Marinoni e Arenhart sustentam que o Código apresenta um equívoco ao misturar julgamento de casos com o julgamento de questões. Observe-se que, no parágrafo único, aparece a questão de direito material ou processual, o que não concorda com o resto do artigo. Segundo os processualistas, a confusão dimana da equalização que o Código recaiu a propósito do papel das Cortes Supremas e das Cortes de Justiça, do precedente e da jurisprudência, do julgamento de casos e do julgamento de questões.

Embora toda e qualquer questão possa ser havida como repetitiva, por sua simples iteração, o incidente de resolução de demandas repetitivas (IRDR) é algo mais complexo e distinto, conforme detalhamento expresso no art. 976 do CPC. Para sua formação devem concorrer, simultaneamente, os seguintes requisitos: efetiva repetição de processos contendo controvérsia sobre a mesma questão unicamente de direito e risco de ofensa à isonomia e à segurança jurídica. Sua razão de existência é a resolução de questões envolvendo direitos individuais homogêneos.

Enquanto o IRDR visa a resolver casos repetitivos, o recurso especial e o extraordinário formam os precedentes ${ }^{32}$. Os recursos repetitivos compõem a base estrutural dos precedentes.

Tratando-se de vinculação vertical, os tribunais não vinculados ao órgão de decisão não estão obrigados a seguir o precedente. Portanto, decisões em incidentes de resolução de demandas repetitivas não vinculam os relatores de tribunais diversos do órgão prolator ${ }^{33}$.

Como se infere da leitura do inc. IV do precitado art. 932, o relator está vinculado, para fins de negativa de provimento, aos acórdãos no julgamento dos casos repetitivos

\footnotetext{
${ }^{32}$ MARINONI, Luiz Guilherme; MITIDIERO, Daniel. Comentários ao Código de Processo Civil: arts. 926 ao 975. 2. ed. São Paulo: Thomson Reuters Brasil, 2018, p. 106.

${ }^{33}$ ZANETI JÚNIOR, Hermes. Poderes do Relator e Precedentes no CPC/2015: perfil analítico do art. 932, IV e V. In: NUNES, Dierle José Coelho. A nova aplicação da jurisprudência e precedentes no CPC/2015: estudos em homenagem à professora Teresa Arruda Alvim. São Paulo: Revista dos Tribunais, 2017, p. 528.
} 
(incidente de resolução de demandas repetitivas e recursos especial e extraordinário repetitivos) e no incidente de assunção de competência.

Trata-se, nessas hipóteses, de vinculação vertical, daí por que as decisões em matéria infraconstitucional, pelo STJ, e, em matéria constitucional, pelo STF, decididas em recursos especial e extraordinário repetitivos, respectivamente, têm força normativa formalmente vinculante para todos os juízes e tribunais, inclusive os próprios tribunais superiores.

\subsection{Depois de facultada a apresentação de contrarrazões, dar provimento ao recurso} se a decisão recorrida for contrária à súmula do Supremo Tribunal Federal, do Superior Tribunal de Justiça ou do próprio tribunal; a acórdão proferido pelo Supremo Tribunal Federal ou pelo Superior Tribunal de Justiça em julgamento de recursos repetitivos ou entendimento firmado em incidente de resolução de demandas repetitivas ou de assunção de competência:

A última hipótese de julgamento, que se ramifica em outras três, envolve o dever de dar provimento ao recurso. Na verdade, trata-se de um espelhamento daquelas inscritas no inc. IV, alíneas "a" a "c", do art. 932 do CPC.

A distinção procedimental é a necessária abertura de vista à parte recorrida para contrarrazões a fim de, somente após, o relator prolatar o julgamento favorável ao recurso em conformidade com as situações jurídicas elencadas nas alíneas "a" a "c" do inc. V do art. 932. Em que pese norma expressa no sentido da obrigatória vista prévia para contrarrazões, em caso de provimento do recurso, localizou-se decisão do Tribunal de Justiça do Rio Grande do Sul em que, já sob a vigência do atual CPC, foi dado provimento a agravo de instrumento, em decisão monocrática, sem prévia abertura ao contraditório ${ }^{34}$. Houve a interposição de agravo interno em tempo de corrigir a nulidade ${ }^{35}$.

O Código não faz referência à abertura de vista ao Ministério Público em segundo grau. Todavia, é imperativa essa oportunização nos casos de intervenção obrigatória como

\footnotetext{
${ }^{34}$ RIO GRANDE DO SUL. Tribunal de Justiça. Agravo de Instrumento n ${ }^{\circ} 70084645068$. Relatora Desa. Maria Isabel de Azevedo Souza. Julgado em 27.out.2020. Disponível em: https://www.tjrs.jus.br/novo/buscassolr/?aba=jurisprudencia\&q=70084645068\&conteudo_busca=ementa_completa Acesso em 24.mai.2021.

${ }^{35}$ RIO GRANDE DO SUL. Tribunal de Justiça. Agravo Interno n ${ }^{\circ} 70084782978$. Relatora Desa. Maria Isabel de Azevedo Souza. Julgado em 15.dez. 2020. Disponível em: https://www.tjrs.jus.br/novo/buscassolr/?aba=jurisprudencia\&q=70084782978\&conteudo_busca=ementa_completa Acesso em 24.mai.2021.
} 
custos juris, sob pena de nulidade (com ressalvas), conforme adiante será mais bem desenvolvido.

\section{A obrigatoriedade de intimação do MP para intervenção no segundo grau nas hipóteses previstas em lei.}

A partir de uma verificação de que integrantes de órgãos fracionários dos tribunais vêm prolatando decisões monocráticas dando ou negando provimento a recursos fora das hipóteses previstas no art. 932 e com inobservância da fundamentação necessária que se extrai da conjugação desse dispositivo com os arts. $927, \S 1^{\circ}$, e $489, \S 1^{\circ}$, todos do CPC, passou-se a perquirir a respeito da intervenção do Ministério Público com atuação no segundo grau nesses recursos.

A pesquisa sumária levou-nos à conclusão de que muitos julgadores sequer oportunizam essa vista dos autos aos procuradores de justiça que atuam como fiscais da ordem jurídica, prolatando diretamente a decisão monocrática em agravos de instrumento e apelações cíveis ${ }^{36}$.

Nos casos de julgamento de agravo de instrumento sem a prévia e necessária vista do caso ao Procurador de Justiça, é cabível o Agravo Interno, conforme previsto no art. 1021 do CPC. O recurso pode e deve ser manejado pelo membro do MP com atuação no segundo grau invocando a nulidade da decisão monocrática que deixou de ser precedida de vista prévia ao parquet, a par de, eventualmente, não ter cumprido toda a liturgia processual da teoria dos precedentes vinculantes prescrita pelo vigente diploma adjetivo civil e amplamente abordada na primeira parte deste trabalho.

Importante destacar que o manejo no atacado desse recurso pelo parquet acabaria por entravar ainda mais o já moroso processo civil brasileiro em detrimento ao escopo do processo que é o alcance do bem jurídico pleiteado pelo jurisdicionado em tempo útil.

Nos julgamentos de apelação, além dos embargos declaratórios cabíveis nos moldes previstos pelo art. 1.022 do CPC (inclusive para fins de prequestionamento), o Procurador

\footnotetext{
${ }^{36}$ Do TJ/RS podemos exemplificar com os Agravos de Instrumento 5064340-23.2021.8.21.7000; 506058151.2021.8.21.7000; 5059740-56.2021.8.21.7000 e com as Apelações Cíveis $\mathrm{N}^{\circ} 70083658443$ e 500143092.2019.8.21.0027/RS; do TJ/SP, recolhemos a Apelações Cíveis 1039467-13.2017.8.26.0506 e 100126578.2019.8.26.0511.
} 
de Justiça pode manejar o Recurso Especial, nas hipóteses previstas na Constituição Federal (art. 105, inc. III). Ao proferir decisão monocrática fora das hipóteses restritas do art. 932 do CPC, estará o julgador, a priori, contrariando texto expresso de lei federal.

$\mathrm{Na}$ sequência, passaremos a uma análise dessas situações que requerem a atuação interveniente do parquet.

A atuação do Ministério Público como fiscal da ordem jurídica (nomenclatura essa congruente com a Constituição de 1988 e que sucedeu ao tradicional custos legis) encontra regência no art. 178 do CPC, que correspondia ao art. 82 do anterior diploma:

Art. 178. O Ministério Público será intimado para, no prazo de 30 (trinta) dias, intervir como fiscal da ordem jurídica nas hipóteses previstas em lei ou na Constituição Federal e nos processos que envolvam:

I - interesse público ou social;

II - interesse de incapaz;

III - litígios coletivos pela posse de terra rural ou urbana.

Parágrafo único. A participação da Fazenda Pública não configura, por si só, hipótese de intervenção do Ministério Público.

Por sua vez, o art. 279 do CPC considera "nulo o processo quando o membro do Ministério Público não for intimado a acompanhar o feito em que deva intervir". Por isso, "se o processo tiver tramitado sem conhecimento do membro do Ministério Público, o juiz invalidará os atos praticados a partir do momento em que ele deveria ter sido intimado" (art. $289, \S 1^{\circ}$ ). Todavia, essa regra é abrandada pela ressalva do $\S 2 .^{\circ}$ do art. 279 , segundo o qual “a nulidade só pode ser decretada após a intimação do Ministério Público, que se manifestará sobre a existência ou a inexistência de prejuízo" e, sobretudo, pela exigência de que a decretação da nulidade tenha por fundamento a ocorrência de efetivo prejuízo ${ }^{37}$.

Trata-se de uma intervenção desinteressada do Ministério Público porque, nesses casos previstos em lei, ele não figura no processo como parte. "Tecnicamente, ele nada pede e nada contra ele é pedido, no sentido de ele não deduz no processo uma pretensão processual nem contra ele uma pretensão processual é deduzida. Sua função, a rigor, é precipuamente a de opinar, ainda que, ao opinar, faça-o em sentido favorável a uma parte e desfavorável a outra" 38 .

\footnotetext{
${ }^{37}$ Nesse sentido: BRASIL. Superior Tribunal de Justiça. Recurso Especial n ${ }^{\circ} 1.694 .984$ - MS. Relator Min. Luis Felipe Salomão. Julgado em: 14.nov.2017. Disponível em: https://corpus927.enfam.jus.br/legislacao/cpc15\#art-279 Acesso em 28.abr.2021.

${ }^{38}$ MARINONI, Luiz Guilherme; MITIDIERO, Daniel e ARENHART, Sérgio Cruz. Comentários ao Código de Processo Civil: arts. 70 ao 187. 2. ed. São Paulo: Thomson Reuters Brasil, 2018, p. 337.
} 
Rio de Janeiro. Ano 15. Volume 22. Número 3. Setembro a Dezembro de 2021

Periódico Quadrimestral da Pós-Graduação Stricto Sensu em Direito Processual da UERJ

Patrono: José Carlos Barbosa Moreira (in mem.). ISSN 1982-7636. pp. 53-81 www.redp.uerj.br

Em que pese a aparente taxatividade do dispositivo, casos outros há que, senão exigem, permitem e até recomendam a intervenção do Ministério Público como custos iuris.

Pode-se afirmar que, nos casos expressos em lei, a obrigatoriedade da intervenção é mandatória. Todavia, outras situações recomendam essa atuação por se enquadrarem em cláusulas abertas como, por exemplo, “interesse público". Recomendável que, na dúvida, o magistrado de qualquer grau de jurisdição abra vista dos autos ao Ministério Público, órgão esse que é o senhor da sua própria intervenção ${ }^{39}$.

Ao elenco do art. 178, o CPC agrega a necessária intervenção do Ministério Público em grau recursal nos chamados incidentes de resolução de demandas repetitivas (art. $\left.976, \S 2^{\circ}\right)$.

Mais recentemente, o advento da Lei $\mathrm{n}^{\circ}$ 13.894/2019, que introduziu diversos mecanismos protetivos contra os casos de violência doméstica originalmente regrados pela chamada "Lei Maria da Penha", acrescentou o parágrafo único ao art. 698 do CPC:

Art.698.

Parágrafo único. O Ministério Público intervirá, quando não for parte, nas ações de família em que figure como parte vítima de violência doméstica e familiar, nos termos da Lei ${ }^{\circ}$ 11.340, de 7 de agosto de 2006 (Lei Maria da Penha).

Outra causa de intervenção autônoma do Ministério Público como fiscal da ordem jurídica advém do art. 75 da Lei ${ }^{\circ}$ 10.741/2003 ( Estatuto do Idoso), in verbis:

Art. 75. Nos processos e procedimentos em que não for parte, atuará obrigatoriamente o Ministério Público na defesa dos direitos e interesses de que cuida esta Lei, hipóteses em que terá vista dos autos depois das partes, podendo juntar documentos, requerer diligências e produção de outras provas, usando os recursos cabíveis.

Observe-se que esse dispositivo há de ser lido e interpretado em conjunto com o art.

74, inc. II, da mesma lei, o qual confere atribuição ao Ministério Público para "promover e acompanhar as ações de alimentos, de interdição total ou parcial, de designação de curador especial, em circunstâncias que justifiquem a medida e oficiar em todos os feitos em que se discutam os direitos de idosos em condições de risco". Parte-se do princípio de que o idoso é presumivelmente capaz, ao contrário do menor de idade. A intervenção irá se justificar em

\footnotetext{
${ }^{39}$ Nesse sentido, "De todo modo, merece ser registrado que ao Ministério Público caberá a valoração da existência do interesse público, de modo que é ilegítima a existência de uma ordem judicial cogente que obrigue sua intervenção, tendo em vista que a independência funcional garante à Instituição a verificação de quando e como exercer suas funções. Se o membro do Ministério Público entender que não é hipótese de sua intervenção e o juiz discordar, os autos deverão ser remetidos ao Procurador Geral, que dará a interpretação definitiva sobre a situação (GODINHO, Robson Renault. O Ministério Público no Novo Código de Processo Civil: alguns tópicos. Revista do Ministério Público do Rio de Janeiro nº 58, out/dez. 2015, p. 243).
} 
Rio de Janeiro. Ano 15. Volume 22. Número 3. Setembro a Dezembro de 2021

Periódico Quadrimestral da Pós-Graduação Stricto Sensu em Direito Processual da UERJ

Patrono: José Carlos Barbosa Moreira (in mem.). ISSN 1982-7636. pp. 53-81 www.redp.uerj.br

duas hipóteses: a) idoso incapaz ou acometido de alguma moléstia que suprima sua capacidade de discernimento e volitiva; b) idoso que, embora dotado dessas capacidades, encontra-se em situação de risco.

Assim, não basta a presença de uma pessoa maior de 60 anos para justificar a intervenção ministerial. Faz-se necessário esteja ela "em condições de risco". Em reforço, vejamos:

AUSÊNCIA DE MANIFESTAÇÃO DO MINISTÉRIO PÚBLICO PARTE IDOSA - LITÍGIO QUE VERSA SOBRE DIREITOS DISPONÍVEIS ENTRE AGENTES CAPAZES - SITUAÇÃO DE RISCO DE PESSOA IDOSA NÃO CONFIGURADA - INTERVENÇÃO MINISTERIAL DESNECESSÁRIA - NULIDADE REJEITADA - 2. LIMITAÇÃO DOS DESCONTOS - SERVIDOR PÚBLICO DO ESTADO DE SANTA CATARINA - MARGEM DE DESCONTOS FACULTATIVOS NO PERCENTUAL DE 40\% DA REMUNERAÇÃO BRUTA, SUBTRAIIDOS OS DESCONTOS OBRIGATÓRIOS, CONFORME DECRETO ESTADUAL N. 2.322/2009 - PARCELA DO EMPRÉSTIMO CONSIGNADO AQUÉM DA PERCENTAGEM PERMITIDA - MANUTENÇÃO - CONTRATOS DE EMPRÉSTIMO PESSOAL COM DESCONTO EM CONTA CORRENTE INVIABILIDADE DE APLICAÇÃO DA LIMITAÇÃO LEGAL DE EMPRÉSTIMOS CONSIGNADOS EM FOLHA DE PAGAMENTO ENTENDIMENTO DO STJ - LIVRE PACTUAÇÃO - RECURSO DO RÉU PROVIDO - 3. REDISTRIBUIÇÃO DOS ÔNUS SUCUMBENCIAIS ANTE A REFORMA DA SENTENÇA - RECURSO DO AUTOR CONHECIDO E IMPROVIDO - RECURSO DO RÉU CONHECIDO E PROVIDO.

1. A intervenção do órgão ministerial em ações envolvendo interesse de idoso somente é obrigatória quando evidenciada situação de risco, a teor dos arts. 43 e 74, II, da Lei n. 10.741/2003.

2. É válido o desconto em conta corrente bancária usada para recebimento de salário, das prestações de contrato de empréstimo bancário livremente pactuado.

3. Modificada a sentença em favor do recorrente, os ônus sucumbenciais são invertidos, devendo o recorrido arcar com a integralidade das despesas processuais e honorários advocatícios ${ }^{40}$.

A intervenção do Ministério Público estabelecida no Estatuto do Idoso ocorre somente em processos que versam sobre interesses sociais ou individuais indisponíveis, em obediência ao artigo 127 da Constituição Federal. O processo em tela não trata de pessoa incapacitada ou em situação de risco, portanto, não há se falar em intervenção ministerial baseada no Estatuto do Idoso. Mérito. - Compete à parte autora na ação de reintegração de posse comprovar os requisitos do artigo art. 561 do CPC, consubstanciados na: a) posse anterior; b) a turbação ou esbulho; c) a data

${ }^{40}$ SANTA CATARINA. Tribunal de Justiça. Apelação Cível n ${ }^{\circ}$ 0302350-23.2014.8.24.0075. Relator Des. Monteiro Rocha. Julgado em: 25/04/2019. Disponível em: http://busca.tjsc.jus.br/jurisprudencia/\#resultado_ancora Acesso em 23.abr.2021. 
em que ocorreu o ilícito; e, d) a continuação ou a perda da posse. Comprovados tais requisitos, é der ser mantida a sentença de procedência. - Não há se falar em direito real de habitação do caso em comento, tendo em vista a total inexistência de provas de que a apelante vivia em união estável com o de cujus, encargo processual que lhe cabia. PRELIMINARES REJEITADAS. APELO DESPROVIDO. UNÂNIME.(Apelação Cível, No 70080457146, Décima Sétima Câmara Cível, Tribunal de Justiça do RS, Relator: Gelson Rolim Stocker, Julgado em: 28-03-2019).

Fixada a situação fática que exige a intervenção ministerial em prol do idoso vulnerável, o art. 76 do Estatuto do Idoso reforça o que o CPC já comanda a necessidade de intimação pessoal do Ministério Público para lançar seu parecer, em qualquer caso.

Pertinente, ainda, ressaltar que o art. 77 comina de expressa nulidade o feito em que essa intimação pessoal do órgão do Ministério Público para lançar seu parecer não ocorra.

Sem embargo, a jurisprudência vinha amenizando o rigor desse preceito, exigindo, em todos os casos de obrigatória intervenção, prova de prejuízo decorrente de sua não ocorrência. Nesse sentido os julgados do Tribunal da Cidadania:

AGRAVO INTERNO NO AGRAVO EM RECURSO ESPECIAL. PROCESSUAL CIVIL. TEMPESTIVIDADE DO RECURSO ESPECIAL. COMPROVAÇÃO. RECONSIDERAÇÃO DA DECISÃO AGRAVADA. FUNDAMENTAÇÃO DO ACÓRDÃO RECORRIDO. SUFICIÊNCIA. NULIDADE. AUSÊNCIA DE INTERVENÇÃO DO MINISTÉRIO PÚBLICO. PREJUÍZO DEMONSTRADO. CONJUNTO FÁTICO-PROBATÓRIO DOS AUTOS. REEXAME. SÚMULA 7/STJ. PRESCRIÇÃO. NÃO OCORRÊNCIA. AGRAVO INTERNO PROVIDO. RECURSO ESPECIAL NÃO PROVIDO. 1. Não se verifica violação ao art. 489 do Código de Processo Civil de 2015, tendo em vista que o acórdão recorrido, embora não tenha examinado individualmente cada um dos argumentos suscitados pela parte, adotou fundamentação suficiente, decidindo integralmente a controvérsia. 2. A jurisprudência desta Corte manifesta-se no sentido de que a ausência de intimação do Ministério Público, por si só, não enseja a decretação de nulidade do julgado, a não ser que se demonstre o efetivo prejuízo às partes ${ }^{41}$ grifamos.

Todavia, esse entendimento vem sendo sensivelmente alterado por julgados mais recentes da mesma Corte, os quais consideram a intimação do Ministério Público imprescindível e não substituível pela simples presença do Procurador em sessão de julgamento. Assim, vejamos o que disse a ementa cuja parte é transcrita:

NECESSIDADE DE INTIMAÇÃO PESSOAL DO PARQUET EM SEGUNDO GRAU NO CASO EM EXAME 4. O acórdão recorrido

\footnotetext{
${ }^{41}$ BRASIL. Superior Tribunal de Justiça. AgInt no AGRAVO EM RECURSO ESPECIAL No 1.529 .823 - RJ. Relator Min. Raul Araújo. Julgado em 18.fev.2020. Disponível em: https://scon.stj.jus.br Acesso em 27.abr.2021.
} 
interpretou equivocadamente o entendimento do Superior Tribunal de Justiça sobre a inexistência de obrigatoriedade da intervenção do Parquet em segunda instância, nos casos em que o Ministério Público figure como autor da Ação Civil Pública, e a não ocorrência, por si só, de nulidade diante da ausência de remessa dos autos a tal órgão em segundo grau. 5. A ausência de intimação do Ministério Público não gera nulidade quando ausente prejuízo, não sendo admissível a interpretação de ser esse ato processual despiciendo. 6. Apesar de a Ação ser ajuizada pelo Ministério Público, o membro que oficia em primeiro grau de jurisdição não atua perante os Tribunais, cabendo essa função ao agente ministerial com atribuições em segunda instância. $\mathrm{O}$ fato de a atuação do membro do Ministério Público em segundo grau como fiscal da lei ou como parte se confundir, em vários casos, não exclui a necessidade de intimação pessoal do membro do Parquet para atos processuais, especialmente no caso dos autos relativos a atos de improbidade administrativa em que patente o interesse público e social. A intimação da Procuradoria de Justiça para conhecer o processo e atuar nele em segundo grau não se confunde com a intimação da pauta de sessão e julgamento, porque as finalidades de cada um desses atos processuais são distintas, razão pela qual a mera indicação da data do julgamento, alguns dias antes, não supre a necessidade de abertura de vista do processo. A comunicação da pauta da sessão informa exclusivamente a data em que o recurso será julgado. A abertura de vista dos autos, por sua vez, permite que o Parquet tome ciência do conteúdo das questões que serão debatidas, apreciadas e julgadas pelo Tribunal e se prepare para eventual sustentação oral, o que garante que a atuação do Procurador de Justiça no julgamento seja efetiva. 9. Na hipótese em exame, o Ministério Público pediu expressamente que fosse realizada sua intimação pessoal para intervir no feito como custos legis antes do julgamento do recurso de Agravo de Instrumento (fls. 71/82), o que, todavia, não ocorreu, com evidente prejuízo ante o provimento do recurso. No mesmo sentido: REsp 1.436.460/PR, Rel. Ministro Og Fernandes, Segunda Turma, DJe 4/2/2019 e REsp 1.637.990/SP, Rel. Ministro Herman Benjamin, Segunda Turma, DJe 18/4/2017 ${ }^{42}$.

No mesmo sentido:

PROCESSUAL CIVIL. ADMINISTRATIVO. IMPROBIDADE ADMINISTRATIVA E PRETENSÃO DO MINISTÉRIO PÚBLICO INTERVIR COMO CUSTOS JURIS. AUSÊNCIA DE INTIMAÇÃO DO REPRESENTANTE DO PARQUET. CONFIGURAÇÃO DE PREJUÍZO NO CASO CONCRETO. I - Trata-se, na origem, de ação civil pública por ato de improbidade administrativa ajuizada pelo Ministério Público do Estado do Paraná. Por sentença, os pedidos foram julgados procedentes para condenar o réu. A Quinta Câmara Cível do Tribunal de Justiça do Estado do Paraná, por unanimidade de votos, deu provimento ao apelo. II - O Tribunal de Justiça do Estado do Paraná entendeu que, no que diz respeito à intimação do Parquet, "em se tratando de demanda na qual a instituição é parte, desnecessária é sua intimação como custos legis, consoante jurisprudência consolidada do Superior Tribunal de Justiça" (fl.

\footnotetext{
42 BRASIL. Superior Tribunal de Justiça. RECURSO ESPECIAL N ${ }^{\circ}$ 1.822.323 - PR. Relator Min. Herman Benjamin. Julgado em 19.set.2019. Disponível em: https://scon.stj.jus.br/SCON/GetInteiroTeorDoAcordao?num_registro=201901793057\&dt_publicacao=11/10 /2019 Acesso em 28.abr.2021.
} 
3.684). III - A fim de validar seu entendimento, citou precedente desta Corte segundo o qual "é desnecessária a intervenção do Ministério Público na qualidade de custos legis quando atua como parte na ação civil pública" (STJ, AgRg no REsp n. 1.385.059/RJ, relator Ministro Benedito Gonçalves, Primeira Turma, DJe de 11/9/2014). Nesse sentido: STJ, AgRg no REsp n. 1.417.765/RJ, relator Ministro Moura Ribeiro, Terceira Turma, DJe de 26/6/2015; STJ, AgRg no REsp n. 1.342.655/RJ, relator Ministro Paulo de Tarso Sanseverino, Terceira Turma, DJe de 11/5/2015. [...] (Aglnt no AREsp n. 698.557/BA, relatora Ministra Assusete Magalhães, Segunda Turma, julgado em 13/9/2016, DJe 27/9/2016)." IV - Ocorre que o Tribunal de origem interpretou equivocadamente aludido entendimento, uma vez que a ausência de intimação do Ministério Público não gera nulidade somente quando inexiste prejuízo, não sendo admissível a interpretação de ser esse ato processual despiciendo. V - É que, "na prática forense, ainda que a ação tenha sido ajuizada pelo Ministério Público, o membro que oficia em primeiro grau de jurisdição não atua perante o Tribunal a quo. Tal função, cabe ao membro do Parquet com atribuições em segundo grau de jurisdição, ainda que a atuação como fiscal da lei ou parte acabe se confundindo em diversas hipóteses, o que não afasta a necessidade de intimação pessoal do agente ministerial (com os respectivos autos) para os atos processuais. Inclusive, em temas de manifesta importância como o caso dos autos, que envolve a prática de atos de improbidade administrativa, não é razoável admitir a afirmação de que não seria necessária a intervenção ministerial no julgamento do recurso" (REsp n. 1.436.460/PR, relator Ministro Og Fernandes, Segunda Turma, julgado em 13/12/2018, DJe 4/2/2019). VI - Na hipótese em exame, o Ministério Público em segundo grau não foi intimado, o que gerou evidente prejuízo, ante a prolação do acórdão que deu provimento à apelação do réu e alterou a sentença de procedência da ação civil pública a fím de declarar inexistente a prática de atos de improbidade administrativa, julgando improcedentes os pedidos iniciais. VII - Cumpre destacar, aliás, que a intimação da Procuradoria de Justiça, para conhecer o processo e nele atuar em segundo grau, não se confunde com a intimação da pauta de sessão e julgamento, porquanto as finalidades de cada um desses atos processuais são distintas, razão pela qual a intimação eletrônica da data do julgamento, alguns dias antes da solenidade, não supre a necessidade de abertura de vista. É que a comunicação da pauta da sessão informa exclusivamente a data em que o recurso será julgado, ao passo que a abertura de vista dos autos permite que o Parquet tome ciência do conteúdo das questões que serão debatidas, apreciadas e julgadas pelo Tribunal e se prepare para eventual sustentação oral, o que garante que a atuação do Procurador de Justiça no julgamento seja efetiva. VIII - Nesse contexto, entendo ser manifesto o prejuízo do Parquet Estadual, ora recorrente, no caso concreto. Nesse sentido: REsp n. 1.822.323/PR, relator Ministro Herman Benjamin, Segunda Turma, julgado em 19/9/2019, DJe 11/10/2019 e REsp n. 1.436.460/PR, relator Ministro Og Fernandes, Segunda Turma, julgado em 13/12/2018, DJe 4/2/2019. IX - Outrossim, não há que falar em incidência da Súmula n. 7/STJ, uma vez que, repitase, é incontroverso que o Ministério Público em segundo grau não foi intimado, o que gerou evidente prejuízo, ante a prolação do acórdão que deu provimento à apelação do réu e alterou a sentença de procedência da 
ação civil pública a fim de declarar inexistente a prática de atos de improbidade administrativa, julgando improcedentes os pedidos iniciais. $\mathrm{X}$ - Agravo interno improvido ${ }^{43}$.

Outra intervenção usual - ainda que não possa ser considerada autônoma porque condicionada ao interesse público - do Ministério Público como fiscal da ordem jurídica dáse nos processos de falência e de recuperação judicial. Após o advento do veto ao art. $4^{\circ 44}$ do projeto que redundou na Lei $\mathrm{n}^{\circ} \mathrm{n}^{\circ}$ 11.101, de 09/02/2005 (Lei de Recuperação de Empresas), houve inequívoca diminuição da atuação do Ministério Público, especialmente na Recuperação Judicial.

De forma diversa do que ocorria sob a égide da revogada Lei de Falências, a intervenção do Ministério Público passa a ser obrigatória somente nas hipóteses previstas na lei ou quando o interesse público assim o sugerir. Nesse sentido, aliás, orienta a Recomendação $n^{\circ} 34 / 2016$ do Conselho Nacional do Ministério Público ${ }^{45}$, incorporada em algumas recomendações estaduais como, por exemplo, a de $n^{\circ}$ 01/2016 do Procurador-Geral de Justiça do Rio Grande do $\mathrm{Sul}^{46}$.

A referida Recomendação do Conselho Nacional do Ministério Público, em seu art. 5o., elenca as hipóteses de relevância social direcionadas para a atuação da instituição como órgão interveniente ao passo que o parágrafo único dispõe o seguinte: "os assuntos considerados relevantes pelo planejamento institucional (art. 1o., inciso I) são equiparados aos de relevância social". Nesse caso, a instituição demonstra o compromisso com o direcionamento de pautas deliberadas como prioritárias.

Expostas as principais situações processuais que demandam ou recomendam a atuação do Ministério Público como órgão interveniente, intuitivo proclamar que, nesses processos, após a sentença ou nos agravos de instrumento, quem atua é o Procurador de Justiça. Portanto, deve ele ser previamente intimado para se manifestar, querendo, antes do julgamento do recurso, seja a decisão monocrática ou não, sob pena de nulidade.

\footnotetext{
${ }^{43}$ BRASIL. Superior Tribunal de Justiça. AgInt no REsp 1889789 / PR. Relator Min. Francisco Falcão. Julgado em 08.mar.2021. Disponível em: https://scon.stj.jus.br/SCON/pesquisar.jsp Acesso em 28.abr.2021.

44 “Artigo 4". o representante do ministério público intervirá nos processos de recuperação e de falência. Parágrafo único - Além das disposições previstas nesta lei, o representante do ministério público intervirá em toda ação proposta pela massa falida ou contra esta"

${ }^{45}$ Disponível em: https://www.cnmp.mp.br/portal/images/Recomendacoes/Recomenda\%C3\%A7\%C3\%A3o0341.pdf Acesso em 28.abr.2021.

${ }^{46}$ Disponível em: https://www.mprs.mp.br/legislacao/recomendacoes/11100/ Acesso em 28.abr.2021.
} 


\section{Conclusões}

A presente pesquisa partiu de um diagnóstico amplo a respeito de um uso abusivo de decisões monocráticas por parte de relatores em recursos cíveis de agravo de instrumento e de apelação, as quais extrapolam as hipóteses do elenco do art. 932 do CPC, ainda que combinados com o rol do art. 927 e sua interpretação extensiva no que diz respeito aos órgãos fracionários que fazem as vezes de plenário, como as Seções do STJ, no caso de embargos de divergência.

Essa prática atenta, a um só tempo, contra os princípios da cooperação (art. $6^{\circ}$ ), do contraditório (especialmente quanto à vedação da decisão surpresa, art. 10, que impede ao juiz decidir sem ouvir as razões das partes e levar essas razões em consideração), da colegialidade (como regra de ouro dos tribunais) e da fundamentação adequada (arts. 489, § $1^{\circ}, \mathrm{V}$ e VI), entre muitos outros. Atenta contra o mandamento expresso do modelo de precedentes vinculantes que determina que na aplicação do precedente as partes e o Ministério Público, quando for o caso, deverão ser ouvidos antes da aplicação do precedente e poderão fundamentar as hipóteses de aplicação e não-aplicação para o caso (art. 927, § 1º, CPC).

A partir do ingresso do processo civil brasileiro do modelo dos precedentes normativos formalmente vinculantes, os tribunais passaram a poder se valer dos precedentes e de sua eficácia vinculativa, mas sempre jungidos a uma técnica processual que passa, necessariamente, pela identificação dos fundamentos determinantes do precedente (circunstâncias fáticas e solução jurídica) somada ao cotejo analítico demonstrativo de que esses se ajustam ao caso posto em julgamento, autorizando a decisão unipessoal pelo relator.

Assim, não basta a simples referência vazia aos dispositivos do CPC, ou a enunciados de súmulas ou de teses jurídicas e, eventualmente, do Regimento Interno do respectivo tribunal, sem a comparação e justificação quanto ao paralelismo entre os casos.

Por fim, nos processos em que o ordenamento jurídico exige a intervenção do Ministério Público como fiscal da ordem jurídica, depois das partes (arts. 178 e 179, CPC), e antes do relator julgar qualquer recurso de forma monocrática, deverá ele abrir vista prévia ao membro do Ministério Público de segundo grau com atribuição para atuar no feito, sob pena de nulidade. 
Essa é a correta interpretação e aplicação do art. 932, VII, CPC, pois o Ministério Público não participa naquele juízo prévio de admissibilidade e mérito que ocorria no regime anterior da apelação e do agravo, ao tempo do Código de 1973.

Queremos dizer, não fala mais antes do julgamento do recurso com a manifestação em primeiro grau sobre a admissibilidade ou mérito do recurso. Portanto, ao julgar sem a oitiva do membro do Ministério Público em segundo grau se está negando vigência à lei federal e atingindo frontalmente o mandamento constitucional que determina a intervenção do Ministério Público como instituição de garantia dos direitos fundamentais, essencial ao sistema jurisdicional, defensora e fiscal da ordem jurídica e dos interesses sociais e individuais indisponíveis (art. 127, CF/1988).

\section{Referências bibliográficas}

BARBOSA MOREIRA, José Carlos. O Futuro da Justiça: alguns mitos. Revista síntese de direito civil e processual civil, Porto Alegre, n. 6 -, Jul/Ago. 2000, p. 36-44.

DIDIER JR., Fredie. Curso de direito processual civil: o processo civil nos tribunais, recursos, ações de competência originária de tribunal e querela nullitatis, incidentes de competência originária de tribunal 13.ed.reform. Salvador: Juspodivm, 2016.

DIDIER JÚNIOR, Fredie; BRAGA, Paula Sarno; OLIVEIRA, Rafael. Curso de direito processual civil: teoria da prova, direito probatório, teoria do precedente, decisão judicial, coisa julgada e antecipação dos efeitos da tutela. 9. ed. Salvador: JusPodivm, 2014, v. 2.

GODINHO, Robson Renault. O Ministério Público no Novo Código de Processo Civil: alguns tópicos. Revista do Ministério Público do Rio de Janeiro nº 58, out/dez. 2015, p. 227-263.

MARCHESAN, Ana Maria Moreira. O fato consumado em matéria ambiental. Salvador: JusPodivm, 2019.

MARINONI, Luiz Guilherme; ARENHART, Sérgio Cruz; MITIDIERO, Daniel. Novo

Código de Processo Civil Comentado. São Paulo: Ed. RT, 2015. p. 493-494. 
MARINONI, Luiz Guilherme; MITIDIERO, Daniel e ARENHART, Sérgio Cruz. Comentários ao Código de Processo Civil: arts. 926 ao 975. 2. ed. São Paulo: Thomson Reuters Brasil, 2018, p. 24-25.

MARINONI, Luiz Guilherme; MITIDIERO, Daniel. Comentários ao Código de Processo

Civil: arts. 926 ao 975. 2. ed. São Paulo: Thomson Reuters Brasil, 2018, p. 106.

MARINONI, Luiz Guilherme; MITIDIERO, Daniel e ARENHART, Sérgio Cruz.

Comentários ao Código de Processo Civil: arts. 70 ao 187. 2. ed. São Paulo: Thomson Reuters Brasil, 2018, p. 337.

MARINONI, Luiz Guilherme. Precedentes obrigatórios. São Paulo: Revista dos Tribunais, 2010.

MIRANDA, Francisco Cavalcanti Pontes de. Comentários ao Código de Processo Civil. Rio de Janeiro: Forense, 1975. t. VII. p. 11.

MITIDIERO, Daniel. Colaboração no processo civil: pressupostos sociais, lógicos e éticos. São Paulo: Revista dos Tribunais, 2009.

NERY JÚNIOR, Nelson; NERY, Rosa Maria Andrade. Comentários ao Código de Processo Civil. 1.ed. São Paulo: Revista dos Tribunais, 2015, p. 1851).

NEVES, Daniel Amorim Assumpção. Manual de direito processual civil. 8. ed. Salvador: JusPodvm, 2016.

VASCONCELOS, Ronaldo; CARNAÚBA, César Augusto. Agravo interno e a decisão monocrática fundada em precedente vinculante: entre a farra, o arbítrio e a prudência.

Revista do Processo, vol. 293, 2019, p. 219-248.

ZANETI JÚNIOR, Hermes. A constitucionalização do processo. 2. ed. São Paulo: Atlas, 2014.

ZANETI JÚNIOR, Hermes. Comentários ao art. 926. In: CABRAL, Antonio do Passo; CRAMER, Ronaldo. Comentários ao Novo Código de Processo Civil. 2. ed. São Paulo: Saraiva, 2016, p. 1314-1315).

ZANETI JÚNIOR, Hermes. Poderes do Relator e Precedentes no CPC/2015: perfil analítico do art. 932, IV e V. In: NUNES, Dierle José Coelho. A nova aplicação da jurisprudência e precedentes no CPC/2015: estudos em homenagem à professora Teresa Arruda Alvim. São Paulo: Revista dos Tribunais, 2017, p. 525-544. 